\title{
Environmental Interest Groups and Authoritarian Regime Diversity
}

\author{
Tobias Böhmelt
}

Published online: 10 December 2013

(C) International Society for Third-Sector Research and The Johns Hopkins University 2013

\begin{abstract}
The literature increasingly disaggregates political systems for examining the differences in international policies and domestic decision-making according to diverse regime typologies. The following research adds to this literature by studying the impact of environmental non-governmental organizations (ENGOs) on the likelihood of ratifying international environmental agreements in different types of autocratic regimes. Building on a theory that focuses on the provision of environmental public goods, the author distinguishes between single-party regimes, military juntas, monarchies, and personalist dictatorships. The core argument claims that the provision of public goods varies among those regime typologies, ultimately leading to the expectation that the lobbying efforts of ENGOs should be most weakly pronounced in those autocracies that are likely to provide more environmental public goods anyway, i.e., single-party regimes. The empirical analysis using data on the ratification of international environmental agreements and autocratic regime types between 1973 and 2006 supports the theory.
\end{abstract}

Résumé La littérature catégorise de plus en plus les systèmes politiques pour étudier les différences entre les politiques internationales et les décisions nationales en fonction des divers types de régimes. L'étude suivante amène sa pierre à l'édifice

This paper has been written in the context of the Swiss NCCR research program "Challenges to Democracy in the 21st Century." I thank Gabriele Spilker, the anonymous reviewers, and the journal's editor, Bernard Enjolras, for helpful comments on an earlier version of this manuscript.

Electronic supplementary material The online version of this article (doi:10.1007/s11266-013-9434-x) contains supplementary material, which is available to authorized users.

T. Böhmelt $(\bowtie)$

University of Essex, Wivenhoe Park, Colchester CO4 3SQ, UK

e-mail: tbohmelt@essex.ac.uk; tobias.boehmelt@ir.gess.ethz.ch

T. Böhmelt

ETH Zurich, Haldeneggsteig 4, 8092 Zurich, Switzerland 
en examinant l'impact des organisations non gouvernementales environnementales (ONGE) sur la probabilité de ratification des accords environnementaux internationaux pour différents types de régimes autocratiques. En s'appuyant sur une théorie centrée sur la fourniture de biens collectifs environnementaux, l'auteur fait la distinction entre les régimes à parti unique, les juntes militaires, les monarchies et les dictatures personnalistes. Cette théorie soutient principalement que la fourniture de biens collectifs varie selon le type de régime et qu'en conséquence finale, le lobbying des ENGO devrait être le plus faible dans les autocraties qui ont par ailleurs davantage tendance à fournir des biens collectifs environnementaux, c'està-dire les régimes à parti unique. L'analyse empirique réalisée à partir des données de ratification des accords environnementaux internationaux et des types de régimes autocratiques entre 1973 et 2006 va dans le sens de cette théorie.

Zusammenfassung In der Literatur werden politische Systeme vermehrt disaggregiert, um die Unterschiede zwischen internationalen Politiken und innerstaatlichen Entscheidungsprozessen entsprechend den verschiedenen Regimetypologien zu untersuchen. Die folgende Forschungsarbeit leistet einen Beitrag zu dieser Literatur, indem die Einflussnahme nicht-staatlicher Umweltorganisationen auf die Wahrscheinlichkeit der Ratifizierung internationaler Umweltverträge in verschiedenen autokratischen Regimen untersucht wird. Der Autor stützt sich auf eine Theorie, die sich auf die Bereitstellung ökologischer öffentlicher Güter konzentriert, und unterscheidet zwischen Einparteienregimen, Militärjunten, Monarchien und personalistischen Diktaturen. Im Wesentlichen wird behauptet, dass die Bereitstellung öffentlicher Güter je nach Regimetypologie variiert, was letztendlich zu der Erwartung führt, dass die nicht-staatlichen Umweltorganisationen in den Autokratien, die wahrscheinlich ohnehin mehr ökologische öffentliche Güter bereitstellen, d. h. in den Einparteienregimen, die geringste Lobbyarbeit leisten sollten. Die empirische Analyse, die Daten über die Ratifizierung internationaler Umweltverträge und autokratische Regimetypen im Zeitraum von 1973 bis 2006 verwendet, unterstützt die Theorie.

Resumen El material publicado desglosa cada vez más los sistemas políticos para examinar las diferencias en las políticas internacionales y en la toma de decisiones nacionales según las diversas tipologías de régimen. La siguiente investigación se añade a este material publicado estudiando el impacto de las organizaciones no gubernamentales medioambientales (ENGO, del inglés environmental non-governmental organizations) sobre la probabilidad de ratificar acuerdos medioambientales internacionales en diferentes tipos de regímenes autocráticos. Partiendo de una teoría que se centra en la provisión de bienes públicos medioambientales, el autor distingue entre regímenes de partido único, juntas militares, monarquías y dictaduras personalistas. El argumento principal plantea que la provisión de bienes públicos varía entre dichas tipologías de régimen, llevando finalmente a la expectativa de que los esfuerzos de presión política de las ENGO deben ser pronunciados más débilmente en aquellas autocracias que es probable que proporcionen más bienes públicos medioambientales, es decir, regímenes de partido único. El análisis empírico utilizando datos sobre la ratificación de acuerdos medioambientales internacionales y tipos de régimen autocrático entre 1973 y 2006 apoya la teoría. 
Keywords Autocratic regimes - Environmental governance $\cdot$ Environmental nongovernmental organizations $\cdot$ Treaty ratification

International policies and domestic decision-making vary significantly among states. Theoretical and empirical explanations for this tend to focus on power or capability aspects, domestic-level characteristics, or regime type. With regard to the latter, the previous work shows, for example, that democracies are less likely than autocracies to fight each other (e.g., Russett and Oneal 2001), are more extensively involved in global trade exchanges (e.g., Mansfield et al. 2000, 2002; Milner and Kubota 2005), or display more environmental-friendly behavior in the realm of environmental governance (e.g., Fredriksson et al. 2005; Lake and Baum 2001; McGuire and Olson 1996; Payne 1995; Bernauer et al. 2010; Congleton 1992; Neumayer 2002a; Ward 2008). The theoretical and empirical insights into states' policy-making provided by these and other studies substantially contributed to our understanding of decision-making processes across regime types. However, while research shed light on the differences between democratic and authoritarian states' international policy-making in general, the study of intra-regime variationespecially with regard to autocratic regime typologies-is not that well developed. In fact, approaches that neglect intra-regime variation essentially treat political systems as a black box, thus ignoring the substantial institutional differences between various forms of democracies and autocracies, and preventing scholars and policymakers alike from getting a more nuanced understanding of the micro foundations at work.

Several recent studies move beyond this black box, though, and explicitly disaggregate political systems for examining if and how regime typologies matter in international relations (e.g., Escribà-Folch 2011, 2012; Escribà-Folch and Wright 2010; Frantz and Ezrow 2011; Leinaweaver 2013; Wright and Escribà-Folch 2012; Ward et al. 2013). For instance, Peceny et al. (2002; see also Peceny and Beer 2003) disaggregate autocracies along single-party systems, military regimes, and personalist dictatorships in order to test their claim of a "dictatorial peace." While robust empirical evidence for the argument that similar autocratic types of states do not fight each other could not be obtained, the authors find considerable variation of conflict behavior across these different regime typologies. Equally influential studies on this topic are given, for example, by Weeks $(2008,2012)$ or Reiter and Stam (2003). Moreover, the importance of disaggregating political systems has not only been proven in the realm of security studies. Bernauer and Koubi (2009), for instance, focus on the impact of political institutions on air quality as measured by states' levels of sulfur emissions. These scholars concentrate on democratic systems, which are disaggregated along presidential and parliamentary systems. The main finding from their study highlights that the former perform better than the latter, i.e., presidential democracies are likely to pollute less. Similarly, albeit with a focus on autocratic regimes, Cao and Ward (2011a, b) and Ward et al. (2013) examine the pollution behavior of different types of dictatorships, i.e., single-party regimes, military juntas, monarchies, and personalist dictatorships. Their paper is not able to find a clear-cut answer on which autocracies are "greener," but it 
produces evidence for significant differences across autocratic typologies. As a result, it seems evident that those and related studies demonstrate the importance of disaggregating political systems by moving beyond the "black box."

The following study seeks to add to this debate by trying to shed light on the impact of environmental non-governmental organizations (ENGOs) ${ }^{1}$ on states' likelihood to ratify international environmental agreements (IEAs) across different types of autocracies. More specifically, does the exerted lobbying influence of ENGOs vary among single-party regimes, military regimes, monarchies, and personalist dictatorships? If so, why and how?

ENGOs may have considerable influence over both policy development processes and their outcomes (Betsill and Corell 2001; Corell and Betsill 2001). A large part of the literature examining ENGOs and their activities documents the strategies used by these organizations to influence environmental politics, and assesses the extent to which these strategies are effective (see Betsill 2006). First and with regard to the typology of strategies, most scholars distinguish between insider and outsider strategies (Betsill 2006; Beyers 2004). The former refer to a set of activities that seek to affect policymakers directly via the provision of expert advice or policy analysis. Corell and Betsill (2001, p. 87) emphasize here that "the provision of knowledge and information is the key ENGO resource for influence" (see also Betsill and Corell 2008). The latter aims at creating pressure from the outside by shaping public opinion (e.g., Gulbrandsen and Andresen 2004; Betsill 2006).

Against this background, the ratification of IEAs generally signals a strong commitment of countries to global environmental cooperation (Fredriksson and Gaston 2000) and, thus, also a strong commitment to the provision of environmental public goods (e.g., Congleton 1992; Lake and Baum 2001; McGuire and Olson 1996). In this context, ENGOs have become regular participants in negotiation processes and exert clearly visible pressure on states toward more "environmentalfriendly" behavior (Betsill and Corell 2001; Corell and Betsill 2001). Existing research shows, for example, that ENGOs can affect states and, hence, international cooperation through the activities outlined above by generating new norms (Finnemore and Sikkink 1998), by motivating governments and legislatures to negotiate international agreements (Raustiala 1997), and by using "their technical, organizational, and lobbying skills" (Chayes and Chayes 1993, p. 204) to enhance the ratification of and compliance with IEAs. Empirically, several studies obtain support for the hypothesis that ENGOs influence states and their degree of environmental cooperation. For example, Roberts et al. (2004) use a cross-section design for studying the ratification rates of 22 IEAs between 1946 and 1999. It is observed that one of the most important predictors of countries' cooperative behavior is pressure from ENGOs. Roberts et al. (2004) conclude that "the number of [E]NGOs in a nation appears virtually synonymous with its likelihood to participate in environmental treaties." More recently, Bernauer et al. (2013) focus on the impact of ENGOs in democracies and argue that ENGOs may not wield a

\footnotetext{
${ }^{1}$ Throughout this article, I use the terms "environmental non-governmental organization (ENGO)," "environmental/green interest group," and "environmental/green lobbying group" interchangeably.
} 
substantial influence in these types of regimes as compared to non-democratic regimes. While ENGOs generally enhance states' ratification of IEAs, this positive effect should be lower in democracies than other forms of government.

In light of the discussion above, however, a shortcoming of Bernauer et al. (2013) is arguably their treatment of non-democratic regimes as a black box. Autocracies are likely to display a substantial variation over their different types also in environmental policy-making. Thus, it seems an effort worth making, both theoretically and empirically, to examine the impact of ENGOs on the likelihood of IEA ratification across different dictatorship typologies. Finding an answer in this regard is also likely to induce crucial policy implications. For instance, while we know that autocracies tend to perform worse in global environmental governance or international cooperation in general, identifying which ones may be more open toward ENGO lobbying influences might clarify where democratic regimes and non-governmental organizations alike could do more. I will return to this issue in the conclusion.

The paper proceeds as follows. The next section develops the theoretical argument. Building on previous accounts of different levels of (environmental) public goods provision according to a country's size of its selectorate and winning coalition, I distinguish between single-party regimes, military juntas, monarchies, and personalist dictatorships. Essentially, my claim is that the provision of public goods varies among those regime types, ultimately leading to the expectation that the lobbying efforts of ENGOs should be most weakly pronounced in those autocracies that have larger winning coalitions and, thus, are more likely to provide higher levels of environmental public goods anyway, i.e., single-party regimes. Afterward, I outline the research design by explaining the variables and the methodology. Using data on the ratification of IEAs and autocratic regime typologies between 1973 and 2006, the succeeding section presents the findings. The last section concludes by summarizing the results and discussing the implications of my research for policymakers and further research.

\section{Selectorate Theory, the Provision of Environmental Public Goods, and Autocratic Regime Type}

\section{General Rationale of the Argument}

Commonly and in any type of autocratic regime, the main incentive of leaders is to stay in power (Tullock 1987; see also Wintrobe 1998; Acemoglu et al. 2004). The argument of this paper agrees with this and combines it with the concepts of the selectorate and the winning coalition. While the former is defined as the subset of the population that controls the fate of and participates in choosing leaders in political systems, the latter is the subset of the selectorate that a leader has to rely on to stay in power (Bueno de Mesquita et al. 1999, 2003).

Bueno de Mesquita et al. $(1999,2003)$ argue here that, in contrast to democracies, non-democratic political leaders typically depend on the support of a smaller winning coalition, which can be compensated with private selective 
incentives, i.e., private goods. Private goods pertain to any exclusionary benefits, e.g., land or money. The benefits of public goods provision, however, are more uniformly distributed among the population. As emphasized by Bueno de Mesquita and Smith (2010, p. 937), "public goods, such as national defense and environmental protection, benefit all members of society." Consequently, if non-democratic leaders decide to invest more in public goods instead of accumulating rents and supplying their selectorate/winning coalition with private goods, a country's elite would incur disproportionately high opportunity costs due to the spending of tax revenues and other resources on the provision of these public goods. In other words, "as [winning] coalition size increases, it becomes increasingly expensive and difficult for leaders to reward their coalition through private rewards, since more people need to be rewarded" (Bueno de Mesquita and Smith 2010, p. 937).

Therefore, this mechanism generates incentives for democratic governments to actually provide public goods, i.e., more generally, for countries with a larger selectorate and winning coalition to invest more in public goods. In this context, Bernauer et al. (2013) show that joining an IEA is simply another form of environmental public goods provision ${ }^{2}$ and policymakers in democratic systems have this incentive even if ENGOs are weak or absent (see also Leinaweaver 2013). Consequently, the impact of ENGOs on states' behavior vis-à-vis IEAs is likely to be weaker in democratic countries, since these regimes tend to pursue "greener" policies anyway.

That said, given those studies that disaggregate autocracies, it seems implausible to assume that autocratic regimes do not vary in their size of the winning coalition and can be treated similarly (e.g., Escribà-Folch 2011, 2012; Escribà-Folch and Wright 2010; Wright and Escribà-Folch 2012; Peceny et al. 2002; Peceny and Beer 2003; Weeks 2008, 2012; Cao and Ward 2011a, b; Ward et al. 2013). Put differently, while I seek to keep the focus on the size of the selectorate and the winning coalition, the likelihood of environmental public goods provision, and the logic on ENGO influence in this regard (Bernauer et al. 2013), the crucial question I have to answer is how the size of the selectorate and the winning coalition varies across autocratic regimes. Conditional on finding an answer in this regard, the ultimate expectations are relatively straightforward: those autocratic typologies that have a selectorate and a larger winning coalition are more likely to provide more public goods-and environmental public goods are certainly not an exception here. If subscribing to this claim, the influence of ENGOs should be more weakly pronounced in those kinds of regimes as a result.

\footnotetext{
2 See also Leinaweaver (2013, pp. 3ff) who states that the ratification of IEAs "greatly resembles what would be involved with the provision of other public goods. This implies that [...] ratification may also speak to and draw from our expectations regarding the autocratic provision of public goods." Moreover, "the ratification of these treaties represents a binding pledge at the international level and domestic groups may view this favorably because they recognize that domestic institutions do not bind the leader very firmly, while international ones, as weak as they are, may provide a more credible binding constraint. Second, compliance with ratified treaties may be assumed as highly likely meaning that the promised environmental goods will be provided" (Leinaweaver 2013, p. 15). Finally, Ward et al. (2013, p. 5) emphasize that "environmental public goods are also important to production, and rulers can invest in future income by protecting them, through implementing environmental regulations."
} 
While the literature offers various classifications of autocracies, I employ an extended framework suggested along the lines of Geddes $(1999,2003)$ and Weeks (2008). This typology categorizes autocracies according to their "different procedures for making decisions, different characteristic forms of intra-elite factionalism and competition, different ways of choosing leaders and handling succession, and different ways of responding to societal interests and opposition" (Geddes 1999, 2003, pp. 48f; Weeks 2008). More specifically, Geddes (1999, 2003) suggests three distinguished types of autocracies: single-party regimes, military regimes, and personalist dictatorships. In addition, Weeks (2008, pp. 47f) also considers monarchies. Mixed regime typologies or so-called hybrid systems will not be taken into account theoretically or empirically in the subsequent sections.

First, single-party regimes are systems where "one party dominates access to political office and control over policy, though other parties may exist and compete as minor players" (Geddes 2003, p. 51). Many single-party governments justify their right to set the rules by fully developed regime ideologies and party platforms - be it of socialist, nationalist, or transnational nature (Lai and Slater 2006, pp. 117f). According to Davenport (2007), this system comes closest to (established) democracies, which can ensure that the foundations of the regime are unlikely to be challenged (Gandhi and Przeworski 2006). Finally, single-party systems frequently entail a certain degree of competition at different levels of administration, e.g., elections allow party candidates competing for the same office (Bratton and van de Walle 1994, pp. 482f). This procedure offers citizens an institutionalized mode of participation.

Second, in military regimes, "a group of officers decides who will rule and exercise some influence on policies" (Geddes 2003, p. 51; see also Peceny et al. 2002, p. 18; Geddes 1999; Frantz and Ezrow 2011); this group also seeks to protect its corporate interests such as the preservation of autonomy, monopoly, and professionalism (Wright and Escribà-Folch 2012). Argentina between 1975 and 1983 is a classic example for this kind of an autocratic system. Despite occasional attempts to develop populist ideologies, the recognition of a military government's right for setting rules rests upon its performance in specific policy fields-most prominently economic growth and national security (Lai and Slater 2006, pp. 117ff). At the same time, policies in military dictatorships are frequently implemented by relatively professional civilian or military bureaucracies (Bratton and van de Walle 1994, pp. 479ff). A certain degree of the rule of law is usually ensured, especially in terms of economic property and other rights that are important for economic growth.

Third, political systems in which a king, queen, or an emir governs (with the help of an extended ruling family) are generally categorized as monarchies. Saudi Arabia provides an example here (Weeks 2008, pp. 47ff). Many monarchies are based on history or tradition, and tend to experience a high degree of stability and longevity. This is the result of the constitutional practice of hereditary succession that mitigates the issue of succession, which is frequently the cause of instability in other types of dictatorships (Olson 2000). However, monarchies usually lack the 
advantages of mass-based political parties, which facilitate the co-option of the citizens (Magaloni 2008).

Fourth, in personalist dictatorships, "access to office and the fruits of office depend much more on the discretion of an individual leader" (Geddes 2003, p. 51), i.e., we observe "the concentration of decision-making and coercive power in the hands of one person, unfettered by a party central committee or institutionalized military decision-making process" (Geddes 2004, p. 13). Consequently, a personalist leader has sole control over policy decisions as well as appointments (Geddes 1999, 2003, 2004). Personalist dictators are likely to consolidate their power either by weakening formal political as well as administrative structures such as party organizations and state bureaucracies or by asserting total control over them. This control over the selection of the inner circle without the constraints of party or military guidelines enables personalist dictator to surround themselves with associates and family members (Frantz and Ezrow 2011). While dictators may build support through the provision of targeted public goods in other types of authoritarian regimes, a personal dictator controls "the flow of public revenues and selectively disburses rewards to a narrow entourage of familial, ethnic, or factional clients. He takes exclusive charge of policy-making (rather than relying on technocratic planning) and implements instructions through personal emissaries (rather than formal institutions)" (Bratton and van de Walle 1994, pp. 474ff; see also Peceny et al. 2002, pp. 17ff; Geddes 2003, p. 227; Weeks 2008, pp. 45f).

The Size of the Selectorate in Autocratic Regimes and the Influence of Environmental Interest Groups: Hypotheses

To recap, Bueno de Mesquita et al. (1999, 2003) show that size of the selectorate and, ultimately, the winning coalition essentially determines whether and to what extent any kind of political system is more likely to provide public goods (see also Bernauer and Koubi 2009, p. 1357). On the one hand, autocratic leaders who can rely on a smaller selectorate and winning coalition provide their supporters generally with a larger amount of private goods, given their main incentive of remaining in power (Bernauer and Koubi 2009, p. 1357). On the other hand, in systems where the selectorate and the winning coalition are relatively large, leaders lack sufficient resources to reward their supporters with high levels of private goods and, in turn, the likelihood of (environmental) public goods provision increases (Bernauer and Koubi 2009, p. 1357).

Against this background, the selectorate and winning coalition in single-party regimes are comprised of party members, which induce that these kinds of autocratic regimes are likely to have the largest selectorate/winning coalition among all autocratic typologies. In addition, Cao and Ward (2011a, p. 9) claim that "the whole military machinery is likely to be included in the selectorate [and, thus, at least partly in the winning coalition], because authoritarian rulers need to rely on the repressive capacity of the military to deal with potential revolutionary threats from the disenfranchised or from coup attempts by rival factions within the selectorate." Hence, my expectation is that, on average, single-party regimes have the largest 
selectorate and winning coalition among autocracies, which is also consistent with Bueno de Mesquita et al. (2003) who associate single-party regimes with large selectorates (Cao and Ward 2011a). Furthermore, the selectorate is the military apparatus itself in a military regime, while, in addition to the military, the selectorate of a monarchy might include all members of the extended royal family (Cao and Ward 2011a, p. 9).

Finally, the classification and ranking of personalist regimes might depend on the way a leader came to power in the first place (Cao and Ward 2011a, p. 10; Geddes 1999). The point that Cao and Ward (2011a) and Geddes (1999) make is essentially that a personalist dictator can emerge from single-party regimes, military juntas, and even monarchies and, in turn, has to include at least fractions from these constituencies as well in her selectorate and winning coalition. Recall, however, the notion by Bratton and van de Walle (1994, pp. 474ff) that a personal dictator "selectively disburses rewards to a narrow entourage of familial, ethnic, or factional clients" and "implements instructions through personal emissaries." In other words, regardless of how a personalist dictator came to power, he will restructure the government apparatus in such a way that induces a relatively small and narrow group of people who a leader has to rely on to stay in power (Bueno de Mesquita et al. 1999, 2003). Thus, on average, the ranking for these four types of regimes by size of the selectorate and winning coalition is the following if we assume "that a dominant party in a single-party regime includes a larger proportion of the population than a typical extended royal family" in a monarchy: (1) single-party regime; (2) monarchy; (3) military regime; (4) personalist regime (Cao and Ward 2011a, p. 9). Therefore, I formulate the following testable hypotheses.

Hypothesis 1 Single-party regimes tend to have the largest selectorate/winning coalition among autocracies and, thus, provide more environmental public goods anyway. The impact of ENGOs is likely to be lowest in this kind of autocratic regime.

Hypothesis 2 Personalist dictatorships tend to have the smallest selectorate/ winning coalition among autocracies and, thus, provide less environmental public goods anyway. The impact of ENGOs is likely to be highest in this kind of autocratic regime.

Hypothesis 3 Due to and depending on the role of the military apparatus, the expectation regarding military regimes or monarchies remains ambiguous. Thus, the impact of ENGOs on the likelihood of IEA ratification may not necessarily differ from other autocratic regime typologies.

\section{Research Design}

Dependent Variable and Methodology

The empirical analysis pertains to countries' ratification behavior vis-à-vis IEAs. The data for ratification are taken from Bernauer et al. (2010). Following these 
scholars, I treat different legal expressions of formally joining a treaty, e.g., accession, as equivalent to ratification. Moreover, treaties that do not deal with environmental issues as central concerns are dropped, and I omit IEAs that opened for ratification before 1973 or that are not open to all countries globally. The unit of analysis is the IEA-country-year, i.e., each IEA is paired with each country that could potentially ratify this IEA in a given year, and each IEA-country pair remains in the data set until the year the respective country ratifies the IEA, but is then dropped. ${ }^{3}$ The final time-series cross-section data cover 150 countries and 268 global environmental treaties between 1973 and $2006 .^{4}$

Against this background, I employ a dependent variable that receives the value of 1 if a country ratifies an agreement in a specific year (0 otherwise). Given the dichotomous nature of this variable, the statistical analysis uses logistic regression models. Robust standard errors are clustered on each IEA-country pair to account for intra-group correlations and other forms of cross-section heterogeneity. Moreover, I control for temporal dependencies by including a ratification-years variable and different sets of cubic splines (Beck et al. 1998). This approach acknowledges that a country's propensity to ratify an IEA might depend on corresponding choices in previous years.

Binary time-series cross-section data are virtually identical to discrete duration data. Hence, instead of the likelihood to ratify an IEA in a given year, I could also focus on the time elapsed between the date when an IEA becomes open for ratification and the date a country ratifies that agreement as more rapid ratification signals a strong commitment to global environmental cooperation (Fredriksson and Gaston 2000). While my main models still rely on the binary-dependent variable and the logistic regression models described above, I also make use of the similarity between binary time-series cross-section data and discrete duration data by employing log-rank tests for the equality of survival functions according to autocratic regime types and the leverage of ENGOs, respectively.

\section{Core Explanatory Variables}

Following my theoretical argument, the core explanatory variables pertain to ENGOs' political leverage and autocratic regime type. First, I define the leverage of ENGOs in terms of the number of national ENGOs registered in a country (see also Fredriksson and Ujhelyi 2006). To this end, I take data from Bernauer et al. (2013) who compiled the information for the time period 1973-2006 in the archives of the International Union for Conservation of Nature. On average, any autocratic regime has about two registered national ENGOs in my sample, while Zimbabwe scores the highest number with 19 registered national ENGOs.

\footnotetext{
${ }^{3}$ Keeping an IEA-country observation in the data after ratification occurred would bias the findings, since this treatment would induce that a country ratifies again and again in each subsequent year.

4 The time period covered by the analysis varies due to data limitations for most of my explanatory variables. While the model without control variables below focuses on the maximum period possible, i.e., 1973-2006, the estimation that considers the control covariates as well covers 1973-2000.
} 
Second, to capture the type of an autocratic political system, I essentially follow the classification provided by Geddes (1999, 2003) and Weeks (2008) and assign country-years to the different regime categories given in the data set by Geddes et al. (2012). This treatment classifies regimes either as a single-party regime, a military regime, a monarchy, or a personalist dictatorship. Mixed regime categories and hybrid regimes are omitted from the analysis and I use (established) democracies as the baseline category, i.e., those country-years that are not coded by Geddes et al. (2012) and score a value of six or higher on the combined polity2 scale of the Polity IV data (Marshall and Jaggers 2004). Democracies represent the highest proportion of country-years in the data $(72.36 \%)$, which I use as the baseline. These are followed by single-party regimes $(11.96 \%)$, personalist dictatorships $(9.42 \%)$, monarchies $(4.51 \%)$, and military regimes $(1.75 \%)$.

Finally, to model the conditional effects of ENGO leverage according to the moderating variables pertaining to the different autocratic regimes, I also consider multiplicative terms between (a) ENGO leverage and monarchy, (b) ENGO leverage and military regime, (c) ENGO leverage and personalist regime, and (d) ENGO leverage and single-party regime. These variables are simultaneously included in the models below, again using democracies as the baseline category.

\section{Control Covariates}

With regard to the control variables, I employ those suggested in Bernauer et al. $(2010)^{5}$ to control for alternative factors that may influence states' ratification behavior (Beron et al. 2003; Congleton 1992; Frank 1999; Fredriksson and Gaston 2000; Fredriksson et al. 2007; Murdoch et al. 2003; Neumayer 2002a, b; Roberts et al. 2004; von Stein 2008). Here, I summarize these control covariates briefly and refer the reader to Bernauer et al. (2010) for a detailed overview of these variables and their underlying theoretical rationales. First, I include data from the Correlates of War Project on a country's membership in international organizations (IO membership), using the number of IOs of which a country is a member in a given year (Pevehouse et al. 2004). Second, I consider a country's trade intensity (or openness), measured as the ratio of the sum of exports and imports to GDP (trade intensity). The data are taken from Gleditsch (2002). Third, I add a variable counting the total number of states in the international system that already ratified an IEA in question until a given year (number of countries ratified). I also include two variables measuring the percentage of countries from the same region (percent of region group ratified) and same income group that already ratified an IEA until a given year (percent of income group ratified). Fourth, I consider income, measured as the log value of GDP per capita (GDP per capita). Given the arguments on the Environmental Kuznets Curve (Seleden and Song 1994; Grossman and Krueger 1995), I also incorporate the square of income. Again, the data are taken from Gleditsch (2002). Fifth, the state of the domestic environment may also influence ratification behavior. Thus, I add the $\log$ of $\mathrm{SO}_{2}$ emissions per capita $\mathrm{SO}_{2}$ per capita), as this type of pollution is arguably the most common form of air pollution.

\footnotetext{
5 If not stated otherwise, the data for the control variables have been taken from this source.
} 
Finally, I include the log of GDP to capture a country's overall economic power $(G D P)$.

\section{Empirical Findings}

I begin the empirical analysis with nonparametric comparisons of survival functions, i.e., estimated probabilities of an IEA not being ratified, according to different types of autocracies. Table 1 summarizes the findings. As illustrated there, a respective survival function and, hence, the probability of IEA ratification varies across autocratic regimes. The $\chi^{2}$ test clearly rejects the null hypothesis of equality of the survival functions. However, Table 1 does not consider the influence of ENGO leverage in this context. Thus, Table 2 takes a more comprehensive perspective by employing a stratified log-rank test, i.e., I test for the equality of the survival functions along the values of ENGO leverage within a nonparametric framework, stratified by the different types of autocratic regimes, i.e., the shapes of the hazards of the different groups differ across each strata. Table 2 summarizes my results here. With this analysis, I obtain some initial support for my theory that the leverage of ENGOs varies across autocratic regimes. The $\chi^{2}$ test is again highly significant and rejects the null hypothesis of equality of survival functions.

While nonparametric approaches allow a preliminary analysis of the data, they largely omit other covariates, particularly the control variables. Thus, the main results of the empirical analysis are summarized in Table 3 where I employ logistic regression models and also consider the control covariates in order to estimate a country's likelihood to ratify an IEA in a given year. While Model 1 focuses on my core explanatory variables only, Model 2 considers the control covariates in addition. The results in this table display simple coefficients for which only the signs and the standard errors can be interpreted directly.

Coming to my hypotheses on the impact of ENGOs in different autocratic regimes on the likelihood of IEA ratification, note that we cannot interpret the signs or standard errors with regard to the constitutive terms of the interactions (see Braumoeller 2004; Brambor et al. 2006). Hence, to further uncover the impact of ENGOs given my moderating variables, I calculated the predicted probabilities of IEA ratification for the values of ENGO leverage according to the four different autocratic regime types with democracies as the baseline category. The results for these estimations are illustrated in Fig. 1 (based on Model 1) and Fig. 2 (based on Model 2). Due to these figures, I can derive the following three conclusions. First, while the data analysis "at least" allows for differences between democracies on one hand and monarchies or military regimes on the other hand, it seems evident that the impact of ENGOs is virtually identical in democratic and single-party systems. The impact of ENGO leverage is different from 0 in either system, but independent from the form of governance at about $0.1 \%$. In other words, I find support for my first hypothesis. Therefore, ENGOs matter in single-party regimes and can exert a positive influence on IEA ratification here. However, given a selectorate/winning coalition in those kinds of autocratic regimes that is likely to be larger than in military regimes, monarchies, or personalist dictatorships (and, in fact, 
Table 1 Log-rank test for equality of survival functions

$\chi^{2}=32.48 ; \operatorname{Pr}>\chi^{2}=0.000$

Table 2 Stratified log-rank test for equality of survival functions

\begin{tabular}{lcc}
\hline & Observed ratifications & Expected ratifications \\
\hline Monarchy & 134 & 168.63 \\
Military regime & 124 & 116.11 \\
Personalist regime & 349 & 404.34 \\
Single-party regime & 497 & 414.92 \\
Total & 1,104 & 1,104 \\
\hline
\end{tabular}

\begin{tabular}{|c|c|c|c|}
\hline \multirow[t]{19}{*}{$\begin{array}{l}\text { Table } 2 \text { Stratified log-rank test } \\
\text { for equality of survival functions }\end{array}$} & $\begin{array}{l}\text { ENGO } \\
\text { leverage }\end{array}$ & $\begin{array}{l}\text { Observed } \\
\text { ratifications }\end{array}$ & $\begin{array}{l}\text { Expected ratifications } \\
\text { (sum over regime typologies) }\end{array}$ \\
\hline & 0 & 155 & 225.27 \\
\hline & 1 & 464 & 523.77 \\
\hline & 2 & 146 & 128.63 \\
\hline & 3 & 112 & 77.37 \\
\hline & 4 & 65 & 41.20 \\
\hline & 5 & 43 & 26.15 \\
\hline & 6 & 28 & 12.93 \\
\hline & 7 & 19 & 9.48 \\
\hline & 8 & 21 & 21.63 \\
\hline & 9 & 29 & 19.67 \\
\hline & 10 & 12 & 3.41 \\
\hline & 11 & 2 & 1.02 \\
\hline & 12 & 3 & 1.19 \\
\hline & 13 & 2 & 2.54 \\
\hline & 14 & 0 & 1.25 \\
\hline & 18 & 1 & 3.96 \\
\hline & 19 & 2 & 4.54 \\
\hline & Total & 1,104 & 1,104 \\
\hline
\end{tabular}

$\chi^{2}=148.73 ; \operatorname{Pr}>\chi^{2}=0.000$

nearly the same as in democracies), the marginal influence of ENGOs is likely to be low due to the fact that either democracies or single-party regimes have per se a strong interest in providing public goods, which applies to environmental public goods equally (see also Bernauer et al. 2013).

Second, the impact of ENGO leverage seems to be most strongly and significantly pronounced in personalist dictatorships. While this holds true in comparison to all other autocratic regimes, i.e., single-party autocracies, military regimes, and monarchies, it also holds in comparison to my baseline category of established democracies. On average, the impact of ENGO influence increases the probability of IEA ratification by less than $0.1 \%$ when one additional ENGO is registered in a democracy. However, this increases to $0.5 \%$ as soon as we examine personalist dictatorships. This finding strongly supports my second hypothesis.

Third, and based upon the previous point, when comparing the diverse autocratic systems with each other, there only seems to be a statistically significant difference 
Table 3 The ratification of international environmental agreements

\begin{tabular}{|c|c|c|}
\hline & Model 1 & Model 2 \\
\hline ENGO leverage & $0.026(0.002)^{* * *}$ & $-0.001(0.003)$ \\
\hline Monarchy & $-0.763(0.120)^{* * *}$ & $-0.625(0.174)^{* * *}$ \\
\hline ENGO $*$ monarchy & $0.069(0.031)^{* *}$ & $0.114(0.058)^{* *}$ \\
\hline Military regime & $-0.496(0.190)^{* * *}$ & $-0.369(0.280)$ \\
\hline ENGO $*$ military & $0.123(0.077)$ & $0.219(0.105)^{* *}$ \\
\hline Personalist regime & $-0.827(0.076)^{* * *}$ & $-0.269(0.117)^{* *}$ \\
\hline ENGO $*$ personalist & $0.178(0.026)^{* * *}$ & $0.162(0.027)^{* * * *}$ \\
\hline Single-party regime & $-0.293(0.062)^{* * *}$ & $0.423(0.087)^{* * *}$ \\
\hline ENGO $*$ single party & $0.001(0.011)$ & $0.037(0.014)^{* * *}$ \\
\hline IO membership & & $0.018(0.002)^{* * *}$ \\
\hline Trade intensity & & $-0.159(0.044)^{* * *}$ \\
\hline Number of countries ratified & & $-0.021(0.001)^{* * *}$ \\
\hline Percent of income group ratified & & $0.041(0.002)^{* * *}$ \\
\hline Percent of region group ratified & & $0.059(0.001)^{* * *}$ \\
\hline GDP per capita & & $1.683(0.408)^{* * *}$ \\
\hline GDP per capita ${ }^{2}$ & & $-0.102(0.025)^{* * *}$ \\
\hline $\mathrm{SO}_{2}$ per capita & & $-0.017(0.028)$ \\
\hline GDP & & $0.106(0.038)^{* * *}$ \\
\hline Ratification-years variable & $0.152(0.019)^{* * *}$ & $-0.245(0.026)^{* * *}$ \\
\hline Spline 1 & $0.022(0.001)^{* * *}$ & $0.009(0.002)^{* * *}$ \\
\hline Spline 2 & $-0.017(0.001)^{* * *}$ & $-0.010(0.001)^{* * *}$ \\
\hline Spline 3 & $0.006(0.000)^{* * *}$ & $0.005(0.001)^{* * *}$ \\
\hline Constant & $-3.752(0.034) * * *$ & $-17.266(1.826)^{* * *}$ \\
\hline Observations & 326,986 & 194,758 \\
\hline Time period & 1973-2006 & 1973-2000 \\
\hline Log pseudolikelihood & $-21,031.71$ & $-11,855.30$ \\
\hline Wald $\chi^{2}$ & $2,273.64$ & $6,858.46$ \\
\hline Prob. $>\chi^{2}$ & 0.00 & 0.00 \\
\hline
\end{tabular}

Standard errors clustered on country-treaty pair in parentheses. Significant at $* 10 \%$, significant at $* *$ $5 \%$, significant at $* * * 1 \%$ (two-tailed)

between single-party regimes and personalist dictatorships. While the latter display a relatively strong and positive impact of ENGO leverage, the former reveal a substantially weaker impact of ENGOs on the likelihood of IEA ratification. The influence of ENGO leverage in monarchies or military regimes, however, does not seem to differ from personalist dictatorships, single-party regimes, or even democracies. This is basically the result of the comparatively large confidence intervals, which in turn are driven by the relatively small number of observations for either monarchies or military regimes. Having said that, it is also in line with my theoretical argument from above that the size of the selectorate and the winning coalition does not necessarily have to vary according to monarchies or military 

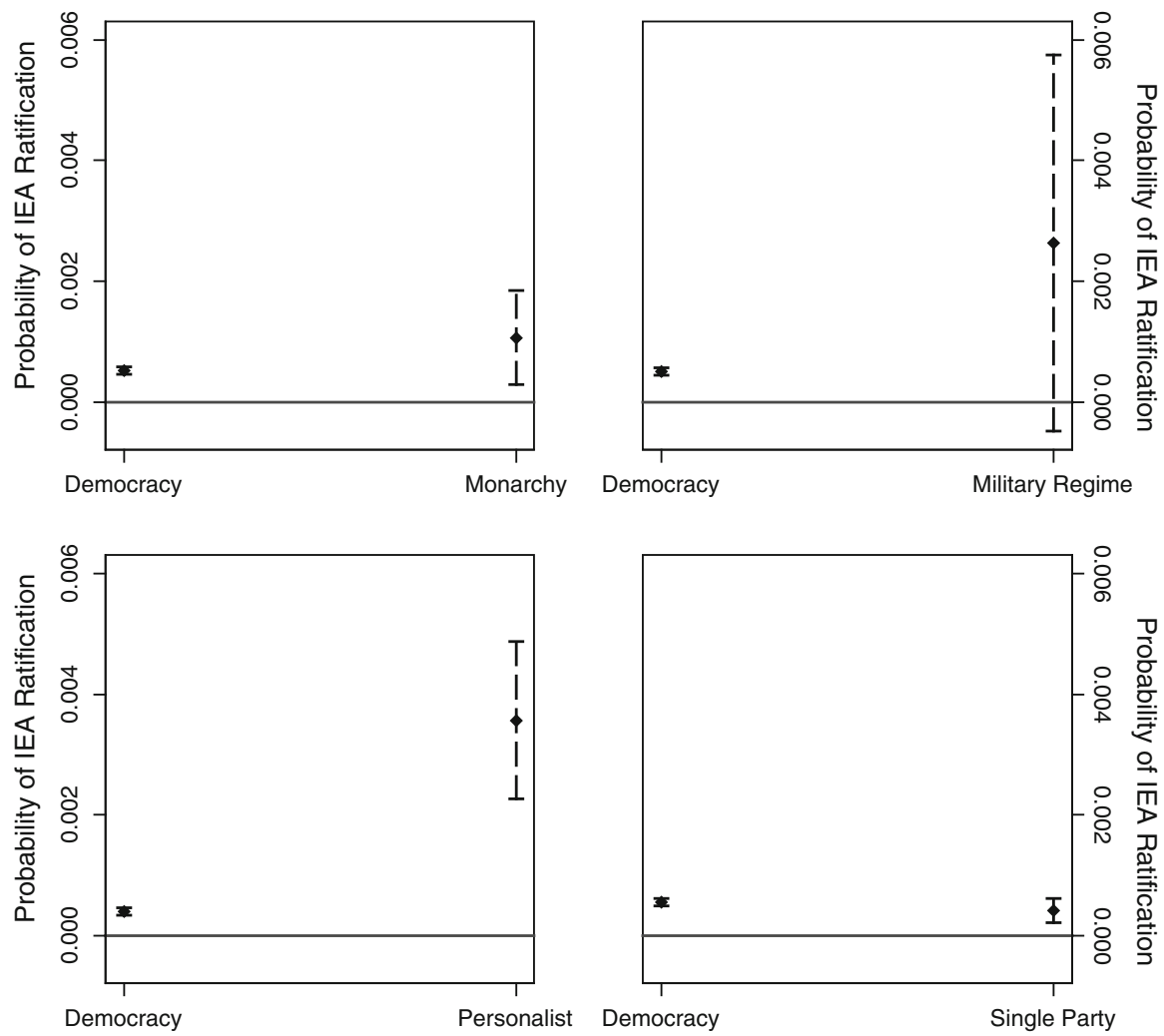

Fig. 1 The impact of ENGO leverage-conditional on autocratic systems (Model 1). Note panels are based on Model 1. Horizontal solid line marks 0 on y-axis. Dashed lines pertain to $90 \%$ confidence interval

regimes; the most substantial difference in the size of the winning coalition and the selectorate should be found between single-party regimes and personalist dictatorships. As a result, I only expected to empirically see a difference in terms of ENGO leverage across these latter regimes.

In sum then, the analysis reveals strong empirical support for my theoretical argument and the derived hypotheses. What remains to be discussed are the control variables. In short, the effects of IO membership, trade intensity, percent of income group ratified, percent of region group ratified, and GDP per capita and its squared term are all in line with previous results reported in the literature. Membership in international organizations significantly increases the likelihood that ratification occurs. When moving from the minimum toward the maximum of this variable, the probability of IEA ratification increases by $1.4 \%$. The same positive impact holds for the percentage of countries of the same region and income group that ratified an IEA, although substantially stronger. More precisely, when moving from the minimum toward the maximum of percent of income group ratified, we see an increase in a country's ratification likelihood of about $16 \%$. In terms of percent of 

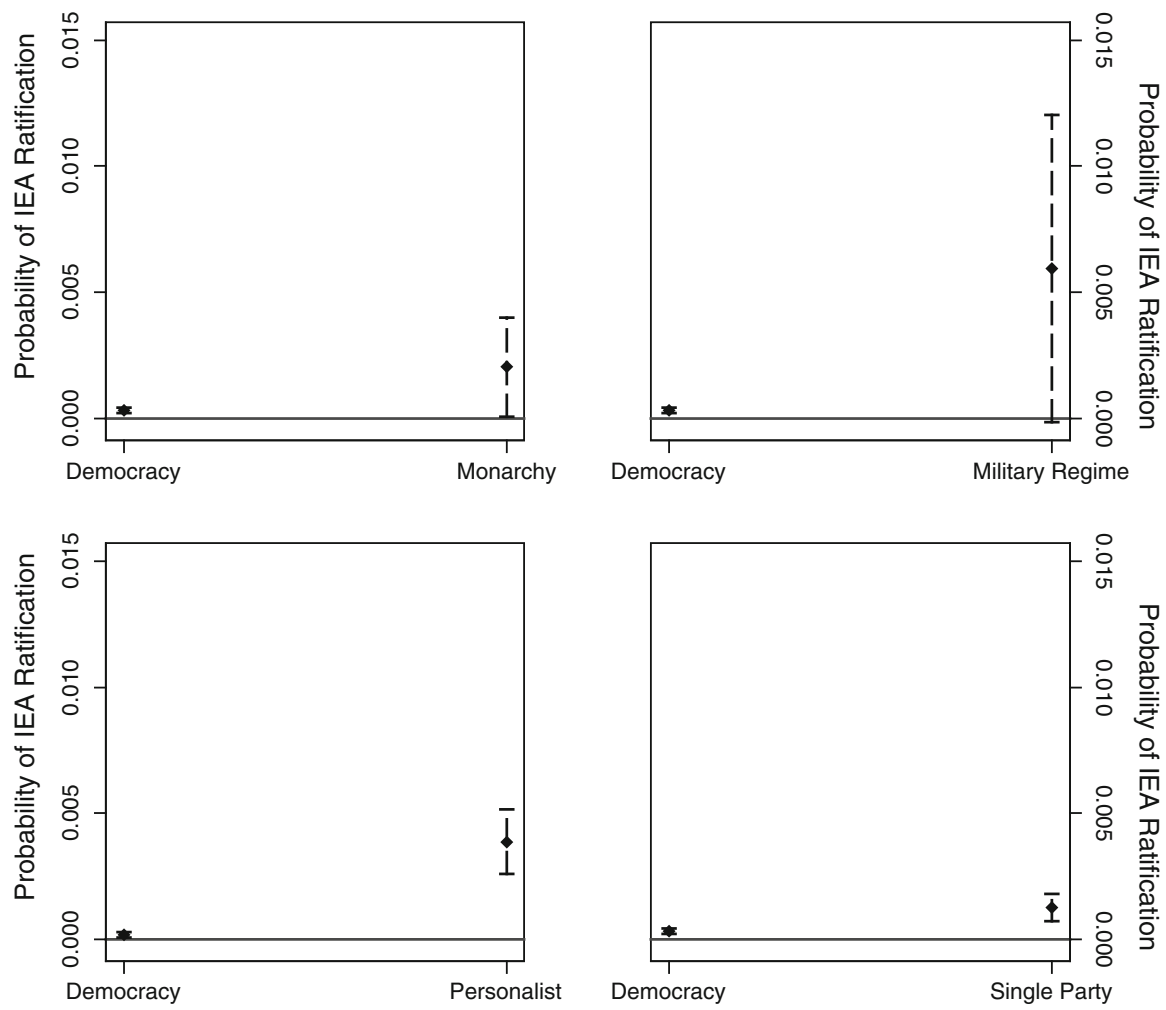

Fig. 2 The impact of ENGO leverage-conditional on autocratic systems (Model 2). Note panels are based on Model 2. Horizontal solid line marks 0 on y-axis. Dashed lines pertain to $90 \%$ confidence interval

region group ratified, the impact is even stronger as we observe a raise by about $53 \%$. Hence, diffusion and learning mechanisms seem to apply for the case of IEA ratification, although it depends on the type of network through which information and ideas flow. More regionally based networks seem to depict a stronger influence. I also find evidence for a curvilinear relationship between GDP per capita and the probability of ratification that mirrors the predicted patterns by the literature on the Environmental Kuznets Curve (Seleden and Song 1994; Grossman and Krueger $1995)$. According to my model, the turning point is associated with $\$ 1,089$. On the other hand, a country's trade intensity contributes to a smaller likelihood of treaty ratification, though with an arguably minor impact. When moving from the minimum toward the maximum of this variable, the chances that a country will ratify an IEA in a given year only decrease by about $0.4 \%$. Further, in contrast to Bernauer et al. (2010), ratification by a given country becomes less likely when a larger share of all other countries has already ratified (about $1 \%$ when increasing number of countries ratified from its minimum to its maximum). At first sight, this might contradict the identified impact of the two other variables on states' ratification. I believe, however, that this is unlikely the case, but merely points to 
countries' patterns of behavior that can be frequently observed at a global level: the larger the group of countries, the less likely it becomes that an individual state's behavior becomes perceptible, and the more likely it is that free-riding occurs (e.g., Olson 1965). Moreover, the impact of countries' economic size is positive, significant, but rather small in substance: the probability of IEA ratification increases only by $0.5 \%$ when moving from the minimum toward the maximum of the variable $G D P$. Finally, domestic environmental conditions as captured by $\mathrm{SO}_{2}$ per capita do not seem to affect the likelihood of treaty ratification in my model substantially.

To assess the robustness of my findings, I ran various alternative model specifications - most prominently, a model estimation that controls for a plausible selection effect. These robustness checks are not discussed in the main text, but summarized in the online appendix. The findings from these specifications further support the results reported here.

\section{Conclusion}

How does the influence of ENGOs on states' ratification behavior toward international environmental agreements vary over autocratic regimes? The existent literature convincingly demonstrates that policies and decision-making with regard to issue areas like security, trade, or the environment not only differ between democracies and non-democratic regimes, but also that there is a substantial amount of intra-group variation. This research sought to add to this literature by focusing on one aspect of global environmental governance, i.e., the ratification likelihood of IEAs, and examining how this is influenced by potential ENGO lobbying efforts in different autocratic systems.

In general, I distinguished between single-party regimes, military juntas, monarchies, and personalist dictatorships. By building on previously developed arguments on the size of a country's selectorate and winning coalition (Bueno de Mesquita et al. 1999, 2003), and the provision of environmental public goods in this context (Bernauer and Koubi 2009; Bernauer et al. 2013), I derived the expectation that single-party regimes are likely to be characterized by a relatively large winning coalition and, thus, may have incentives to provide more environmental public goods than other autocracies anyway. However, this should weaken the marginal lobbying influence of ENGOs. In contrast, personalist dictatorships should, on average, have the smallest winning coalition among autocratic regime typologies and, thus, may aim for private goods at the expense of (environmental) public goods. Hence, while this type of autocratic regime should be least conducive toward ENGOs in the first place, the marginal impact of these green lobbying groups should be more strongly pronounced than in any other autocratic regime if ENGOs do exist. The empirical analysis using methods for binary time-series cross-section data and discrete duration data found strong and robust support for the argument. The impact of ENGOs is indeed most strongly pronounced in autocratic regimes that have a personalist dictator. On the other hand, ENGOs still have an absolute positive 
impact on the likelihood of IEA ratification in single-party regimes, but this influence appears much weaker there.

Arguably, this paper intends to add to the increasing literature on disaggregated autocratic regime types. I hope that I was able to shed some light on an important, albeit rarely addressed issue. Needless to say, however, that many important questions remain, thus opening interesting avenues for further research. First, the ratification of an IEA signals a strong commitment toward environmental quality and the provision of environmental public goods. Nevertheless, another crucial aspect in this regard may be an actual outcome measure, i.e., emissions (e.g., Ward et al. 2013). Do ENGOs also have the ability to influence these? If so, how-and does this also vary across (autocratic) regime types?

Second, given the importance of outcome measures, further research might want to study the impact of ENGOs within a broader framework of signature, ratification, and outcome. Recent research demonstrates that those factors leading to signature may also influence the latter two concepts (see Baccini and Urpelainen 2013). If this applies, we must study states' environmental behavior in more complete frameworks that consider all of those issues. This conclusion not only applies to studies of ENGO impact or to disaggregated political systems, but more generally for the discipline.

Moreover, I also believe that some important policy implications can be derived from this study. For example, I could show that the marginal influence of ENGOs is likely to be highest in personalist dictatorships. However, these kinds of autocratic systems are also likely to be more hostile toward the establishment of a civil society in the first place. Efforts by international organizations, states, and nongovernmental organizations themselves to strengthen civil society systematically may further lead to a more positive impact on these legitimate actors even in nondemocratic systems. Ultimately, this could induce processes of democratization, thus having a more far-reaching impact that goes beyond environmental governance exclusively.

Moreover, from a normative view that may demand ENGOs to push governments toward more ambitious environmental policies, this research suggests that ENGO lobbying efforts are not without any effect. In fact, while the ENGO impact differs significantly across autocratic regime typologies, it remains positive in absolute terms in all systems on average. By identifying such an overall net impact of ENGOs, my research complements the existing literature, which offers such evidence in more idiosyncratic form for specific environmental policy areas, countries, and points in time.

Finally, I also provide a more nuanced perspective on the generally held view that autocracies are likely to be less environmental friendly than democratic regimes. ENGOs pursue interests that seek to preserve the environment. Given that they exist in autocratic forms of government and that they have an influence, we might want to re-examine the relationship between autocracies and environmental behavior more thoroughly.

Conflict of interest The author declares "no conflict of interest." 


\section{References}

Acemoglu, D., et al. (2004). Kleptocracy and divide-and-rule: A model of personal rule. Journal of the European Economic Association, 2(2-3), 162-192.

Baccini, L., \& Urpelainen, J. (2013). Before ratification: Understanding the timing of international treaty effects on domestic policies. International Studies Quarterly,. doi:10.1111/isqu.12080.

Beck, N., et al. (1998). Taking time seriously: Time-series cross-section analysis with a binary dependent variable. American Journal of Political Science, 42(4), 1260-1288.

Bernauer, T., \& Koubi, V. (2009). Effects of political institutions on air quality. Ecological Economics, 68(5), 1355-1365.

Bernauer, T., et al. (2010). A comparison of international and domestic sources of global governance dynamics. British Journal of Political Science, 40(3), 509-538.

Bernauer, T., et al. (2013). Is there a democracy-Civil society paradox in global environmental governance? Global Environmental Politics, 13(1), 88-108.

Beron, K. J., et al. (2003). Why cooperate? Public goods, economic power, and the Montreal Protocol. Review of Economics and Statistics, 85(2), 286-297.

Betsill, M. M. (2006). Transnational actors in international environmental politics. In M. M. Betsill, K. Hochstetler, \& D. Stevis (Eds.), Palgrave advances in international environmental politics (pp. 172-202). Houndmills: Palgrave Macmillan.

Betsill, M. M., \& Corell, E. (2001). NGO influence in international environmental negotiations: A framework for analysis. Global Environmental Politics, 1(4), 65-85.

Betsill, M. M., \& Corell, E. (Eds.). (2008). NGO diplomacy. The influence of nongovernmental organizations in international environmental negotiations. Cambridge, MA: MIT Press.

Beyers, J. (2004). Voice and access: Political practices of European interest associations. European Union Politics, 5(2), 211-240.

Brambor, T., et al. (2006). Understanding interaction models: Improving empirical analysis. Political Analysis, 14(1), 63-82.

Bratton, M., \& van de Walle, N. (1994). Democratic experiments in Africa-Regime transitions in comparative perspective. Cambridge: Cambridge University Press.

Braumoeller, B. (2004). Hypothesis testing and multiplicative interaction terms. International Organization, 58(4), 807-820.

Bueno de Mesquita, B., \& Smith, A. (2010). Leader survival, revolutions, and the nature of government finance. American Journal of Political Science, 54(4), 936-950.

Bueno de Mesquita, B., et al. (1999). An institutional explanation of the democratic peace. American Political Science Review, 93(4), 791-807.

Bueno de Mesquita, B., et al. (2003). The logic of political survival. Cambridge, MA: MIT Press.

Cao, X., \& Ward, H. (2011a). Authoritarian regimes and environmental performance: A supply-side account. Colchester: University of Essex.

Cao, X., \& Ward, H. (2011b). Constituency size, extractive capacity power, and pollutionEnvironmental implications from an authoritarian politics model. Colchester: University of Essex.

Chayes, A., \& Chayes, A. H. (1993). On compliance. International Organization, 47(1), 175-205.

Congleton, R. D. (1992). Political institutions and pollution control. Review of Economics and Statistics, 74(3), 412-421.

Corell, E., \& Betsill, M. M. (2001). A comparative look at NGO influence in international environmental negotiations: Desertification and climate change. Global Environmental Politics, 1(4), 86-106.

Davenport, C. (2007). State repression and the tyrannical peace. Journal of Peace Research, 44(4), 485-504.

Escribà-Folch, A. (2011). Group strength, accountability, and growth under dictatorship. International Political Science Review, 32(1), 5-22.

Escribà-Folch, A. (2012). Authoritarian responses to foreign pressure: Spending, repression, and sanctions. Comparative Political Studies, 45(6), 683-713.

Escribà-Folch, A., \& Wright, J. G. (2010). Dealing with tyranny: International sanctions and the survival of authoritarian rulers. International Studies Quarterly, 54(2), 335-359.

Finnemore, M., \& Sikkink, K. (1998). International norm dynamics and political change. International Organization, 52(4), 887-917.

Frank, D. J. (1999). The social bases of environmental treaty ratification, 1900-1990. Sociological Inquire, 69(4), 523-555. 
Frantz, E., \& Ezrow, N. M. (2011). The politics of dictatorship: Institutions and outcomes in authoritarian regimes. Boulder, CO: Lynne Rienner Publishers.

Fredriksson, P. G., \& Gaston, N. (2000). Ratification of the 1992 climate change convention: What determines legislative delay? Public Choice, 104(3/4), 345-368.

Fredriksson, P. G., \& Ujhelyi, G. (2006). Political institutions, interest groups, and the ratification of international environmental agreements. Houston, TX: Department of Economics, University of Houston.

Fredriksson, P. G., et al. (2005). Environmentalism, democracy, and pollution control. Journal of Environmental Economics and Management, 49(2), 343-365.

Fredriksson, P. G., et al. (2007). Kyoto Protocol cooperation: Does government corruption facilitate environmental lobbying? Public Choice, 133(1/2), 231-251.

Gandhi, J., \& Przeworski, A. (2006). Cooperation, cooptation, and rebellion under dictatorships. Economics and Politics, 18(1), 1-26.

Geddes, B. (1999). Authoritarian breakdown: Empirical test of a game theoretic argument. Los Angeles: University of California at Los Angeles.

Geddes, B. (2003). Paradigms and sand castles: Theory building and research design in comparative politics. Ann Arbor, MI: University of Michigan Press.

Geddes, B. (2004). Minimum-winning coalitions and personalization in authoritarian regimes. Los Angeles: University of California at Los Angeles.

Geddes, B., et al. (2012). Authoritarian regimes: A new data set. Los Angeles: University of California at Los Angeles, CA.

Gleditsch, K. S. (2002). Expanded trade and GDP data. Journal of Conflict Resolution, 46(5), 712-724.

Grossman, G. M., \& Krueger, A. B. (1995). Economic growth and the environment. Quarterly Journal of Economics, 110(2), 353-377.

Gulbrandsen, L., \& Andresen, S. (2004). NGO influence in the implementation of the Kyoto Protocol: Compliance, flexibility mechanisms, and sinks. Global Environmental Politics, 4(4), 54-75.

Lai, B., \& Slater, D. (2006). Institutions of the offensive: Domestic sources of dispute initiation in authoritarian regimes, 1950-1992. American Journal of Political Science, 50(1), 113-126.

Lake, D., \& Baum, M. (2001). The invisible hand of democracy: Political control and the provision of public service. Comparative Political Studies, 34(6), 587-621.

Leinaweaver, J. (2013). Autocratic ratification: Environmental cooperation to prolong survival. Springfield, MO: Drury University.

Magaloni, B. (2008). Credible power-sharing and the longevity of authoritarian rule. Comparative Political Studies, 41(4-5), 715-741.

Mansfield, E. D., et al. (2000). Free to trade: Democracies, autocracies, and international trade. American Political Science Review, 94(2), 305-321.

Mansfield, E. D., et al. (2002). Why democracies cooperate more: Electoral control and international trade agreements. International Organization, 56(3), 477-513.

Marshall, M. G., \& Jaggers, K. (2004). POLITY IV project: Political regime characteristics and transitions, 1800-2004. Dataset user's manual. College Park, MD: University of Maryland.

McGuire, M., \& Olson, M. (1996). The economics of autocracy and majority rule: The invisible hand and the use of force. Journal of Economic Literature, 34(2), 72-96.

Milner, H. V., \& Kubota, K. (2005). Why the move to free trade? Democracy and trade policy in the developing countries. International Organization, 59(1), 107-143.

Murdoch, J. C., et al. (2003). The participation decision versus the level of participation in an environmental treaty: A spatial probit analysis. Journal of Public Economics, 87(2), 337-362.

Neumayer, E. (2002a). Do democracies exhibit stronger international environmental commitment? A cross-country analysis. Journal of Peace Research, 39(2), 139-164.

Neumayer, E. (2002b). Does trade openness promote multilateral environmental cooperation? World Economy, 25(6), 815-832.

Olson, M. (1965). The logic of collective action: Public goods and the theory of groups. Cambridge, MA: Harvard University Press.

Olson, M. (2000). Power and prosperity: Outgrowing communist and capitalist dictatorships. New York: Basic Books.

Payne, R. A. (1995). Freedom and the environment. Journal of Democracy, 6(3), 41-55.

Peceny, M., \& Beer, C. (2003). Forum: Peaceful parties and puzzling personalists. American Political Science Review, 97(2), 339-342.

Peceny, M., et al. (2002). Dictatorial peace? American Political Science Review, 96(1), 15-26. 
Pevehouse, J. C., et al. (2004). The COW-2 international organizations dataset version 2.0. Conflict Management and Peace Science, 21(2), 101-119.

Raustiala, K. (1997). States, NGOs, and international environmental institutions. International Studies Quarterly, 41(4), 719-740.

Reiter, D., \& Stam, A. C. (2003). Identifying the culprit: Democracy, dictatorship, and dispute initiation. American Political Science Review, 97(2), 333-337.

Roberts, T. J., et al. (2004). Who ratifies environmental treaties and why? Institutionalism, structuralism, and participation by 192 nations in 22 treaties. Global Environmental Politics, 4(3), 22-64.

Russett, B., \& Oneal, J. R. (2001). Triangulating peace: Democracy, interdependence, and international organizations. New York: W. W. Norton \& Company.

Seleden, T. M., \& Song, D. (1994). Environmental quality and development: Is there a Kuznets curve for air pollution emissions? Journal of Environmental Economics and Management, 27(2), 147-162.

Tullock, G. (1987). Autocracy. Boston: Kluwer Academic Publisher.

von Stein, J. (2008). The international law and politics of climate change. Journal of Conflict Resolution, 52(2), 243-268.

Ward, H. (2008). Liberal democracy and sustainability. Environmental Politics, 17(3), 386-409.

Ward, H., et al. (2013). State capacity and the environmental investment gap in authoritarian states. Comparative Political Studies (in press).

Weeks, J. (2008). Autocratic audience costs: Regime type and signaling resolve. International Organization, 62(1), 35-64.

Weeks, J. (2012). Strongmen and straw men: Authoritarian regimes and the initiation of international conflict. American Political Science Review, 106(2), 326-347.

Wintrobe, R. (1998). The political economy of dictatorship. Cambridge: Cambridge University Press.

Wright, J., \& Escribà-Folch, A. (2012). Authoritarian institutions and regime survival: Transitions to democracy and subsequent autocracies. British Journal of Political Science, 42(2), 283-309. 